\title{
Alteration in the blood biochemical parameters and degenerative lesions in Rat liver by a common pyrethroid insecticide (Bifenthrin)
}

Muhammad Salman Ikram ${ }^{1}$, Tahir Mehmood ${ }^{1 *}$, Faiza Siddique ${ }^{1}$, Iqra Abdul Sattar ${ }^{1}$, Qudsia Tabassam ${ }^{1}$ and Zahra Jabeen ${ }^{2}$

1. Department of Chemistry, University of Sargodha, Sargodha-40100-Pakistan

2. Department of Applied chemistry \& Biochemistry, Government College University, Faisalabad-Pakistan

*Corresponding author's email: tahiruosbiochem@yahoo.com; tahirmehmood@uos.edu.pk

Citation

Muhammad Salman Ikram, Tahir Mehmood, Faiza Siddique, Iqra Abdul Sattar, Qudsia Tabassam and Zahra Jabeen. Alteration in the blood biochemical parameters and degenerative lesions in Rat liver by a ccommon pyrethroid insecticide (Bifenthrin). Pure and Applied Biology. Vol. 5, Issue 4, pp1051-1063.

http://dx.doi.org/10.19045/bspab.2016.50130

Received: $18 / 09 / 2016$

Revised: 23/09/2016

Accepted: 27/09/2016

Online First: 28/09/2016

\section{Abstract}

In this study the effects of oral administration of bifenthrin (BF) on biochemical and histological parameters of male rat's liver have been evaluated. Dose response was evaluated on different groups of rats with respect to different time interval of 2, 8 and 31 days. Divided the animals in four groups as A, B, $\mathrm{C}$ and D. Group B, C and D received bifenthrin concentration $(60 \mathrm{mg} / \mathrm{kg}$ per body weight), (70 $\mathrm{mg} / \mathrm{kg}$ body per weight) and ( $85 \mathrm{mg} / \mathrm{kg}$ per body weight), respectively. Group A is as control and each and every animal in this group received equal volume of mustard oil without BF. Finding being observed in the rats treated group with bifenthrin showed dose dependent signs and severity of acute/sub-acute poisoning meticulously that is they were more severe as the dose concentration was increased. Collection of the blood sample and the serums were used for analyses of lipid profile, proteins (serum albumin, serum globulins and serum total proteins/STP, serum albumin) and different liver enzymes. It was observed that a higher concentration of bifenthrin raised level of cholesterol in all the treated groups while the HDL level decreases and the Level of LDL in treated group was higher as compared to normal rats. The higher levels of AST and ALT in the treated rats were observed as compared to the normal group in relation to time and doses employed. Moreover, a high concentration of BF doses shows decreasing trend of the concentration of total serum protein, serum albumin and globulins decreased. In addition it has observed that bile duct hyperplasia along with degenerative changes in hepatocytes by histopathological examination of liver and there was dose dependent severity. Our data reports the toxic actions of bifenthrin at different doses administered during the study which produced biochemical alterations in serum profile and moderate histological lesions in liver.

Keywords: Bifenthrin; Blood biochemical parameters; Degenerative lesions; Rat liver

\section{Introduction}

Pesticides usage is being wide all around the world and it is increasing day by day. The important fact about pesticides are that they are performing a key role in meeting the food, tobacco, cotton fiber and demand of increasing population and ultimately control the viral diseases. Occupational contact of 
different pesticides is definitely to identify the different side effects of pesticides usage of enormous interest and purpose to establish the safe methods of pesticide usage. In spite of all important factors there is key point that because pesticide mishandling in different departments of the agriculture which has been linked with different health problems and environmental contagion globally [1-3].

It is commonly observed that an extensive variety of pesticides which contain bifenthrin having the public health problem and lots of challenges. It is established that bifenthrin belongs to the class of potent synthetic pyrethroid. It has been observed that most of the products are used in the our common daily usage and have high agricultural values are protected by pesticides containing bifenthrin which includes cereals, cotton, corn, alfalfa, hay, grass seed, some fruits, ornamentals, and vegetables. It is also very common to see that pyrethroids containing bifenthirn are strongly hydrophobic and have a quality to absorb the particular material that are always remain embedded to make its sediments so it is to be rather dissolve in water column but short-term aqueous exposures may impact pelagic organisms. The physiochemical properties of a chemical have a strong potential to determine its environmental suitability and its behavior and potential outcome. According to different data that metabolism of bifenthrin took place very quickly into different metabolites in the liver. Process of metabolism done by hydrolysis of the ester linkage, oxidation of aromatic rings and methyl groups by conjugation reactions [4].

It is also observed that hepatic and lipid profile results have been addressed in a few studies in animals, so far present study is a typical in regard to long term repetitive treatments and follows up.
There is established fact that effect of pesticides on the clinical health effects adversely under the action of enzymes of liver which are mostly used as a marker [5]. There is extensive contact to many pesticide, affected liver and kidneys, [6] there is also a raise in the occurrence of liver disorders among Ranch Hand workers in large contact category [7]. If we statistically analyzed then there is comparatively high level of aspartate aminotransferase (AST) were found in agriculture workers who are constantly exposed to pesticides [8]. Most of industrial workers who are steadily exposed to pesticides the elevated levels of gamma glutamyl transferase (GGT) were found in the blood of $[8,9]$. It has also been observed that high amount of liver dysfunction was observed with elevated (AST), alanine aminotransferase (ALT), or lactate dehydrogenase (LDH) [7-11]. Studies revealed that AST and ALT produces their effects on the process of breakdown of amino acids into $\alpha$ - keto acid which are in flight for complete metabolism through the Kreb's cycle and electron transport chain. As a result they are measured as a specific marker for liver damage [12]. AST and ALT in serum shows there amplified activity to indicated hepatocellular dysfunctions [13]. Many studies has been reported a productive correlation of pesticides with the liver enzymes [6, 14]. Total cholesterol (TC), HDL-C, triglycerides (TGs) make a standard lipid profile. Lipid profiles are risk factors of coronary artery disease. Bifenthrin adversely affect all parameters including liver enzymes, serum protein and particular lipid profile as compared to other type of pyrethroid.

Bifenthrin (BF) is a pyrethroid (PYR) insecticide. The target points for PYR's toxic action are voltage sensitive sodium channels in the central nervous system (CNS). Intoxication with PYRs results in motor activity impairment and death in 
insects. Poisoning with $\mathrm{BF}$ decreases locomotor activity in a single dose proportionate manner. $\mathrm{BF}$ damages also the liver and alters blood morphology [15]. Hepatic pathology in pyrethroid exposed animals observed in many studies, thus far present study is also weird with this regard to interval and more clearly correlates the biochemical alterations with hepatic histopathology. The aim of our studies was to checked the bifenthrin effects of physicochemical behavior, acute toxicity of bifenthrin on different blood bio-parameters (Lipid profile, AST, ALT, ALP, blood protein and to assess the histopathologic consequences of liver organ) so that bifenthrin have adverse effects on rat's health so proper precautions needed be taken in use of this pesticide to care about human's health.

\section{Materials and methods}

In the present study all experiments were carried out according to all the national legislations and research principles laid down by the Ethics Committee about the animal welfare and following the strategies of the University of Sargodha, Sargodha. All efforts were made to minimize the number of animals used and their suffering.

\section{Experimental protocol}

Generally healthy Swiss albino mature (adult) male rats $(n=32)$ about of the similar age (almost 3 months) and weight $(200 \pm 40 \mathrm{~g})$, were obtained from Department of Pharmacy, Islamia University Bahawalpur and were held in reserve under particular same supervision conditions. The overall animal room temperature was maintained at $24-28^{\circ} \mathrm{C}$ with $46-65 \%$ humid condition and 12-h light-dark cycle all over the study. Rats served with a verity of foods which were available for them in market, and gave them three times a day. After 5 days accommodation rats were divided into four equal groups at random order i.e., group A served as control group while the B, C and $\mathrm{D}$ group manifested as treated group administrated bifenthrin orally, which purchased from local grain market of Sargodha. Oral (lethal dose) LD50 of bifenthrin in male rats is $70 \mathrm{mg} . \mathrm{kg}-/$ body weight [16]. It is observed that bifenthrin is not soluble in water so mustard oil for oral administration used to dissolve it. Dose to be oral administrated was attuned according to body weight. Groups B, C and D received low, medium and high $(60,70 \& 85 \mathrm{mg} / \mathrm{kg}$ body weight doses, respectively) after 48 hours, 8 days and up to 31 days. The importance of body weight measuring of is subjected to the animal weight was recorded on weekly basis. The overall utilization of food and the temperature of rectal monitored on daily basis. All animal were monitored twice daily to observe various clinical signs of toxicity. To observe the physical behavior the clinical sign in each animal scored on the basis of severity signs (---- to ++++) and did comparison with control group A.

\section{Collection of samples and analyses}

Blood samples from all animals were collected after every treatment of doses of pesticide and were subjected to taking out of serum. Temperature for storing of blood sample was very important so the serum sample for biochemical studies after collection stored at $-20^{\circ} \mathrm{C}$. Triglycerides (TG), cholesterol, HDL (High density lipoprotein) and LDL (Low density lipoprotein) measured done by enzymatic colorimetric with a spectrophotometer. By using the commercially available colorimetric kits (AMP Medizintechnic GmbH, Austria Cat \# BR0415, BR061 \& BR0202, respectively) activities of the different liver enzymes were calculated one by one and these enzymes includes serum aspartate aminotransferase (AST), alanine aminotransferase (ALT) and alkaline phosphatase (ALP) activities. Measurements of the different enzymes particular AST and ALT were measured to evaluate the activity and concentration of L-lactate or L-Malate 
with $\alpha$-ketoglutarate at wavelength of 340 $\mathrm{nm}$, while p-nitrophenol with water concentration's was measured by evaluating the activity of ALP at wavelength of $405 \mathrm{~nm}$ with a spectrophotometer. Biuret method and serum albumin by bromocresol green (BCG) dye binding method used for the assessment of serum total proteins (STP) by spectrophotometer [14]. By subtraction of albumin from STP we have calculated serum globulin [17]. In the present study histopathological examination done by dissecting the liver from each animal [18, 19]. In present study process of histopathology were followed by taking the $5 \mathrm{~mm}$ thick pieces of the melancholic organ were fixed in $10 \%$ buffered formalin and after that using routine methods of dehydration, paraffin embedding, sectioning (4-5 $\mu \mathrm{m}$ ) and staining. After going through this session slides which has been prepared after following the above procedure then observed the histological lesions by microscopic examination of slides of each group and were scored on a scale of ----- to +++++ . From this a collective lesion score was derived for the overall severity of pathology in a particular group.

Statistical analysis

Table 1. Bifenthrin various doses were administrated to rats shows signs of incidence and its prevalence of clinical symptoms

\begin{tabular}{|c|c|c|c|c|c|c|}
\hline \multirow[t]{3}{*}{ Parameter } & \multicolumn{6}{|c|}{ Group (BF dose: mg.kg $^{-1}$ b.wt) } \\
\hline & \multicolumn{2}{|c|}{ B (60) } & \multicolumn{2}{|c|}{$\mathrm{C}(\mathbf{7 0})$} & \multicolumn{2}{|c|}{ D (85) } \\
\hline & $\mathrm{F}^{*}$ & $\mathbf{I}^{* * *}$ & $\mathbf{F}$ & I & $\mathbf{F}$ & I \\
\hline Skin irritation & ++-- & 50 & +++- & 70 & ++++ & 80 \\
\hline Coarse tremors & ++-- & 20 & +++- & 30 & ++++ & 60 \\
\hline Dullness & ++-- & 40 & +++- & 60 & ++++ & 70 \\
\hline Low body & ++-- & 50 & +++- & 60 & ++++ & 80 \\
\hline \multicolumn{7}{|l|}{ Temperature } \\
\hline Lacrimation & ++- & 55 & +++- & 65 & ++++ & 78 \\
\hline Dilation of pupil & ++- & 28 & +++- & 45 & ++++ & 60 \\
\hline \multicolumn{7}{|l|}{ Movement } \\
\hline Gasping & +++- & 35 & +++- & 60 & ++++ & 70 \\
\hline Ptyalism & ++-- & 50 & ++-- & 60 & ++++ & 80 \\
\hline
\end{tabular}

Frequency $(* \mathrm{~F})$ Incidence $(* * \mathrm{I})(\%)$. Different of concentrations of bifenthrin (BF) with mustard oil were administration to the rats at different period. In a day two times animals were monitored for clinical signs. Various clinical signs in each animal were scored on the basis of severity (------- to ++++++). Control group A did not show any clinical sign
In this study Two-way ANOVA test was applied and the overall data collected was then analyzed by using variance SPSS-20 statistical software package on my personal computer. For this purpose the analysis of variance was also applied on all sampling days collectively to obtain the whole results. By Tukey multiple Range Test (TMR) at 0.05 - level of significance, the means of various treatments were compared [20].

\section{Results}

\section{Frequency and incidence of clinical signs}

The various doses of bifenthrin showed amplified action to exterior stimuli particular group B, C and D and did comparison with group A which was control. It is also observed that slighter appeal towards feed and water and as well as showed dullness, lacrimation, breathless and ptyalism in dose treated groups (Table 1). There was Itching/scratching also amplified. It has been observed that all above effects become more pronounced between 15 minutes and $1.5 \mathrm{~h}$ after each oral administration and vanished within 12-24 hours in all animals. Frequency signs indicated severity of doses and incidence showed how many animals were suffered due to treatments. 


\section{Total cholesterol \& triglycerides}

The level of cholesterol was higher in all groups of treatment as compared to the normal group, but it was found significantly higher in higher dose administrated group D, all results of total cholesterol \& triglycerides presented in (Table 2).
In case of triglycerides (TGLs) the level were remarkably increased in all treated groups as compared to control group significantly $(\mathrm{P} \leq 0.05)$. The difference on TGLs value between day 2 and day 8 , day 2 and day 31 (Table 2) and as well day 8 to day 31 not significantly differ $(\mathrm{P} \geq 0.05)$.

Table 2. Bifenthrin various doses were administrated to rats shows different values of serum total cholesterol \& triglycerides.

\begin{tabular}{|c|c|c|c|c|c|}
\hline \multirow{2}{*}{$\begin{array}{l}\text { Parameter } \\
\text { Exp. Day }\end{array}$} & \multicolumn{4}{|c|}{ Group (BF dose:mg.kg-1b.wt) } & \multirow[t]{2}{*}{ P-Value } \\
\hline & $\mathbf{A}(\mathbf{0})$ & B (60) & $\mathbf{C}(\mathbf{7 0})$ & D (85) & \\
\hline \multicolumn{6}{|c|}{ Cholesterol (mg. dl $\left.{ }^{-1}\right)$} \\
\hline 2 & $65.00 \pm 1.00$ & $71.33 \pm 2.08$ & $65.00 \pm 1.00$ & $81.67 \pm 3.21$ & 0.034 \\
\hline 8 & $64.12 \pm 1.31$ & $69.62 \pm 2.01$ & $65.01 \pm 1.01$ & $78.00 \pm 3.22$ & 0.013 \\
\hline 31 & $65.0 \pm 1.34$ & $71.23 \pm 2.06$ & $63.22 \pm 1.13$ & $80.22 \pm 3.12$ & 0.033 \\
\hline Overall & $65.08 \pm 1.32$ & $70.69 \pm 2.21$ & $64.06 \pm 1.12$ & $80.16 \pm 3.11$ & 0.001 \\
\hline \multicolumn{6}{|c|}{ Triglycerides $\left(\mathrm{mg}^{\left.-\mathrm{dl}^{-1}\right)}\right.$} \\
\hline 2 & $69.67 \pm 1.53$ & $119.67 \pm 1.53$ & $127.00 \pm 2.00$ & $141.33 \pm 1.53$ & 0.000 \\
\hline 8 & $68.23 \pm 1.33$ & $119.10 \pm 1.52$ & $126.33 \pm 2.01$ & $139.02 \pm 1.33$ & 0.001 \\
\hline 31 & $66.10 \pm 1.51$ & $117.23 \pm 1.50$ & $127.22 \pm 2.33$ & $139.33 \pm 1.01$ & 0.013 \\
\hline Overall & $66.55 \pm 1.39$ & $120.01 \pm 1.50$ & $125.01 \pm 2.19$ & $140.22 \pm 1.31$ & 0.000 \\
\hline
\end{tabular}

The values (mean $\pm \mathrm{SD}$ ) having different numbers in row vary in significance $(\mathrm{P} \leq 0.05)$. Exp.day (Experimental day). Different concentration of bifenthrin (BF) mixed in mustord oil where administrated orally to rats at various intervals. Blood samples with use of the anticoagulant from all animals were collected at different time for immediate analysis

\section{HDL \& LDL level}

The significantly $(\mathrm{P} \leq 0.05)$ low level of HDL were measured in almost all treatment group specially in $\mathrm{B}$ and $\mathrm{C}$ as doses high as HDL is go down as compared to control group. There is not a significant $(\mathrm{P} \geq 0.05)$ difference between day 2 to day 8 and day 2 to day 31 and even from day 8 to day 31 (Table 3). The results revealed that HDL decrease is dose dependent but not time dependent.

High level of LDL were recorded in $\mathrm{C}$ and $\mathrm{D}$ treated groups compared to control group but it is not significantly ( $\mathrm{P} \geq 0.05)$ increased in group B as compared to control group. In time dependent mode there is significantly $(\mathrm{P} \leq 0.05)$ difference between days 2 day 8 but not significantly $(\mathrm{P} \geq 0.05)$ difference between day 2 to day 31 and day 8 to day 31 , the results are shown in (Table 3 ).

\section{Total proteins, albumin and globulin}

In present study a dose dependent very slight declining trend was observed in serum total proteins (STP) concentration in all treatment groups as compared to not treated group (Table 4). Significantly $(\mathrm{P} \leq 0.05)$ elevated STP was recorded in group $\mathrm{C}$ as compared to control group, group B and group D. In time dependent mode only significant difference $(\mathrm{P} \leq 0.05)$ at experimental days 8 and 31 in groups $C$ and D was found. It shows that changes in STP in not dependent strongly on time and dose of bifenthrin.

Significantly $\quad(\mathrm{P} \leq 0.05) \quad$ lower $\quad$ serum albumins were recorded in group $\mathrm{D}$ as compared to control; $\mathrm{B}$ and $\mathrm{C}$ group results are presented in (Table 4). As for as time is concerned there was almost no significant $(\mathrm{P} \geq 0.05)$ difference between days, the significant difference of decrease in serum 
globulins was recorded in all treated groups as compared to control group except in group $\mathrm{C}$ where increase in globulin level was observed.

Table 3. Bifenthrin various doses were injected to rats shows serum HDL \& LDL level.

\begin{tabular}{|c|c|c|c|c|c|}
\hline \multirow{2}{*}{$\begin{array}{l}\text { Parameter } \\
\text { Exp. Day }\end{array}$} & \multicolumn{4}{|c|}{ Group (BF dose:mg.kg-1b.wt) } & \multirow[t]{2}{*}{ P-Value } \\
\hline & $\mathbf{A}(\mathbf{0})$ & B (60) & $\mathbf{C}(\mathbf{7 0})$ & D (85) & \\
\hline \multicolumn{6}{|c|}{ HDL (mg. dl-1) } \\
\hline 2 & $11.66 \pm 0.57$ & $11.33 \pm 1.15$ & $8.33 \pm 0.57$ & $6.66 \pm 0.57$ & 0.698 \\
\hline 8 & $10.22 \pm 0.61$ & $11.01 \pm 1.01$ & $8.01 \pm 1.01$ & $6.21 \pm 0.56$ & 0.002 \\
\hline 31 & $11.31 \pm 0.63$ & $11.19 \pm 1.14$ & $8.22 \pm 0.69$ & $6.58 \pm 0.51$ & 0.000 \\
\hline Overall & $10.32 \pm 0.59$ & $11.21 \pm 1.01$ & $8.23 \pm 0.65$ & $6.23 \pm 0.62$ & 0.006 \\
\hline \multicolumn{6}{|c|}{ LDL (mg. dl $\left.{ }^{-1}\right)$} \\
\hline 2 & $38.33 \pm 1.53$ & $38.67 \pm 3.51$ & $43.33 \pm 2.08$ & $45.67 \pm 1.53$ & 0.894 \\
\hline 8 & $38.22 \pm 1.31$ & $37.22 \pm 3.12$ & $42.66 \pm 2.11$ & $45.33 \pm 1.31$ & 0.044 \\
\hline 31 & $36.55 \pm 1.69$ & $38.22 \pm 3.44$ & $42.11 \pm 2.01$ & $46.22 \pm 1.69$ & 0.004 \\
\hline Overall & $37.49 \pm 1.55$ & $38.43 \pm 3.15$ & $41.22 \pm 2.69$ & $45.17 \pm 1.33$ & 0.068 \\
\hline
\end{tabular}

The values (mean \pm SD) having different letters in row differ in significance $(\mathrm{P} \leq 0.05)$. Exp.day (Experimental day). Different concentration of bifenthrin (BF) mixed in mustord oil where administrated orally to rats at various intervals. Blood samples with use of the anticoagulant from all animals were collected at different time for immediate analysis.

Table 4. The serum total proteins, albumin and globulin in rats administrated with different dose of bifenthrin.

\begin{tabular}{|c|c|c|c|c|c|}
\hline \multirow{2}{*}{$\begin{array}{l}\text { Parameter } \\
\text { Exp. Day }\end{array}$} & \multicolumn{4}{|c|}{ Group (BF dose:mg.kg-1 b.wt) } & \multirow[t]{2}{*}{ P-Value } \\
\hline & $\mathbf{A}(\mathbf{0})$ & B (60) & $\mathrm{C}(\mathbf{7 0})$ & D (85) & \\
\hline \multicolumn{6}{|c|}{ Total serum protein $\left(\right.$ g. $\left.\mathrm{dl}^{-1}\right)$} \\
\hline 2 & $6.16 \pm 0.05$ & $6.33 \pm 0.15$ & $7.06 \pm 0.40$ & $6.43 \pm 0.11$ & 0.219 \\
\hline 8 & $6.12 \pm 0.15$ & $6.12 \pm 0.19$ & $7.15 \pm 0.14$ & $6.14 \pm 0.17$ & 0.110 \\
\hline 31 & $6.11 \pm 0.11$ & $6.52 \pm 1.12$ & $8.22 \pm 0.59$ & $6.56 \pm 1.00$ & 0.011 \\
\hline Overall & $6.11 \pm 0.22$ & $6.92 \pm 1.11$ & $7.55 \pm 0.51$ & $6.41 \pm 1.13$ & 0.128 \\
\hline \multicolumn{6}{|c|}{ Serum Albumin (g. $\left.\mathrm{dl}^{-1}\right)$} \\
\hline 2 & $3.43 \pm 0.18$ & $3.22 \pm 1.08$ & $3.33 \pm 0.59$ & $3.13 \pm 0.56$ & 0.639 \\
\hline 8 & $3.42 \pm 0.19$ & $3.17 \pm 1.11$ & $3.21 \pm 0.61$ & $3.24 \pm 0.61$ & 0.016 \\
\hline 31 & $3.39 \pm 0.18$ & $3.59 \pm 1.16$ & $3.19 \pm 0.63$ & $3.11 \pm 0.89$ & 0.611 \\
\hline Overall & $3.12 \pm 0.88$ & $3.66 \pm 1.19$ & $3.22 \pm 0.91$ & $3.22 \pm 0.12$ & 0.110 \\
\hline \multicolumn{6}{|c|}{ Total serum globulins $\left(\right.$ g. $\left.\mathrm{dl}^{-1}\right)$} \\
\hline 2 & $3.30 \pm 0.10$ & $3.16 \pm 0.05$ & $3.30 \pm 0.10$ & $3.13 \pm 0.20$ & 0.139 \\
\hline 8 & $3.31 \pm 0.15$ & $3.18 \pm 0.19$ & $4.10 \pm 1.01$ & $3.22 \pm 0.71$ & 1.000 \\
\hline 31 & $3.94 \pm 0.98$ & $3.22 \pm 0.18$ & $3.12 \pm 1.00$ & $3.21 \pm 1.11$ & 0.338 \\
\hline Overall & $3.33 \pm 0.12$ & $3.22 \pm 0.01$ & $3.15 \pm 1.02$ & $3.91 \pm 0.22$ & 0.216 \\
\hline
\end{tabular}

The values (mean $\pm \mathrm{SD})$ having different letters in row differ in significance $(\mathrm{P} \leq 0.05)$. Exp.day (Experimental day). Different concentration of bifenthrin (BF) mixed in mustord oil where administrated orally to rats at various intervals. Blood samples with use of the anticoagulant from all animals were collected at different time for immediate analysis

\section{AST, ALT and ALP}

The considerably $(\mathrm{P} \leq 0.05)$ higher $\mathrm{AST}$, ALT and ALP level as contrast to control group was recorded in all treated group. As the dose increases, the AST level also increases in group $\mathrm{B}, \mathrm{C}$ and D. Significantly $(\mathrm{P} \leq 0.05)$ higher AST 
level as for as treatment time is concerned there was a difference between days 2,8 and 31 . This result demonstrated that AST is time and dose dependent (Table 5).

Table 5. Serum AST, ALT and ALP in rats administrated with different dose of bifenthrin

\begin{tabular}{|c|c|c|c|c|c|}
\hline \multirow{2}{*}{$\begin{array}{l}\text { Parameter } \\
\text { Exp. Day }\end{array}$} & \multicolumn{4}{|c|}{ Group (BF dose:mg.kg-1b.wt) } & \multirow[t]{2}{*}{ P-Value } \\
\hline & $\mathbf{A}(\mathbf{0})$ & B $(60)$ & $\mathrm{C}(\mathbf{7 0})$ & D (85) & \\
\hline \multicolumn{6}{|c|}{ Aspartate transaminase (U/L) } \\
\hline 2 & $108.33 \pm 1.53$ & $120.00 \pm 1.00$ & $124.33 \pm 1.15$ & $135.00 \pm 1.00$ & 0.002 \\
\hline 8 & $107.17 \pm 1.33$ & $119.12 \pm 1.01$ & $126.52 \pm 1.33$ & $138.31 \pm 1.12$ & 0.001 \\
\hline 31 & $107.53 \pm 1.21$ & $121.44 \pm 1.22$ & $129.43 \pm 1.34$ & $143.44 \pm 1.22$ & 0.000 \\
\hline Overall & $108.12 \pm 1.05$ & $120.44 \pm 1.10$ & $126.55 \pm 1.63$ & $140.55 \pm 1.32$ & 0.006 \\
\hline \multicolumn{6}{|c|}{ Alanine transaminase (U/L) } \\
\hline 2 & $74.66 \pm 0.57$ & $76.67 \pm 1.53$ & $83.67 \pm 1.15$ & $94.00 \pm 2.65$ & 0.168 \\
\hline 8 & $74.27 \pm 0.12$ & $76.55 \pm 1.33$ & $87.22 \pm 1.27$ & $98.55 \pm 2.82$ & 0.007 \\
\hline 31 & $76.19 \pm 0.51$ & $76.22 \pm 1.61$ & $90.17 \pm 1.29$ & $99.22 \pm 2.84$ & 0.006 \\
\hline Overall & $75.22 \pm 0.63$ & $76.52 \pm 1.53$ & $86.22 \pm 1.11$ & $96.56 \pm 2.33$ & 0.600 \\
\hline \multicolumn{6}{|c|}{ Alkaline phosphatase (U/L) } \\
\hline 2 & $162.00 \pm 1.00$ & $164.67 \pm 1.53$ & $170.33 \pm 2.52$ & $181.67 \pm 1.53$ & 0.085 \\
\hline 8 & $160.10 \pm 1.01$ & $164.15 \pm 1.11$ & $174.12 \pm 2.15$ & $185.25 \pm 1.22$ & 0.033 \\
\hline 31 & $162.12 \pm 1.19$ & $167.12 \pm 1.43$ & $178.55 \pm 2.04$ & $187.15 \pm 1.66$ & 0.002 \\
\hline Overall & $161.22 \pm 1.11$ & $166.22 \pm 1.21$ & $175.51 \pm 2.33$ & $185.14 \pm 1.51$ & 0.021 \\
\hline
\end{tabular}

The values (mean $\pm \mathrm{SD}$ ) having different letters in row differ in significance $(\mathrm{P} \leq 0.05)$. Exp.day (Experimental day). Different concentration of bifenthrin (BF) mixed in mustord oil where administrated orally to rats at various intervals. Blood samples with use of the anticoagulant from all animals were collected at different time for immediate analysis

\section{Histological examination}

In the present study the rats of control group (A) did not show any histological alteration in liver. The group treated with dose rate of 60 mg.kg-1 (by weight) exhibited that moderate bile duct hyperplasia along with degenerative changes in hepatocytes, while the group treated with dose rate 70 mg.kg-1 (by weight) dose exhibit condensed nuclei of hepatocytes and necrosed hepatocytes. This study also revealed that in the higher doses and such changes become more rigorous and widespread having the swelling at cell level and muddled pattern like hepatic cord hepatic (Table 6). The 4th group treated 85mg.kg-1 (by weight) dose exhibited that bile duct and hepatocytes necrosis of hepatocytes Figure 1 (A-D).

Table 6. Bifenthrin various doses were administrated to rats shows signs of incidence and its prevalence of histological lesions in liver

\begin{tabular}{|l|l|l|l|l|l|l|l|l|}
\hline \multirow{2}{*}{ Lesion } & \multicolumn{9}{c|}{ Group (BF dose: mg.kg-1 b.wt) $^{-1}$} \\
\cline { 2 - 9 } & \multicolumn{2}{|c|}{ A (Control) } & \multicolumn{2}{c|}{ B (60) } & \multicolumn{3}{c|}{ C (70) } & \multicolumn{2}{c|}{ D (85) } \\
\cline { 2 - 10 } & $F^{*}$ & I* & F & I & F & I & F & I \\
\hline Hyperplasia of bile duct & +--- & 10 & ++--- & 20 & +++-- & 40 & +++++ & 80 \\
\hline Degeneration & +---- & 10 & ++--- & 30 & +++-- & 60 & ++++- & 90 \\
\hline Cytoplasm vacuolation & +----- & 10 & ++-- & 60 & +++-- & 80 & ++++- & 100 \\
\hline
\end{tabular}

Frequency $(* \mathrm{~F})$ Incidence $(* * \mathrm{I})(\%)$. Different of concentrations of bifenthrin (BF) with mustard oil were administration to the rats at different period. At the end of experiment animal dissected. For histological purpose slides prepared and conserved for scoring the overall lesion from samples of liver tissues in each group were measured on the basis of severity (---- to ++++). As a result general strengths of lesions were scored in a collective manner. Control A group exhibit very negligible lesion 
Degenerative changes were observed in histopahtological studies of the rat's liver which is explained in term of frequency and incidence which showed that how much liver damaged in treated groups and in how many rats liver injured respectively.
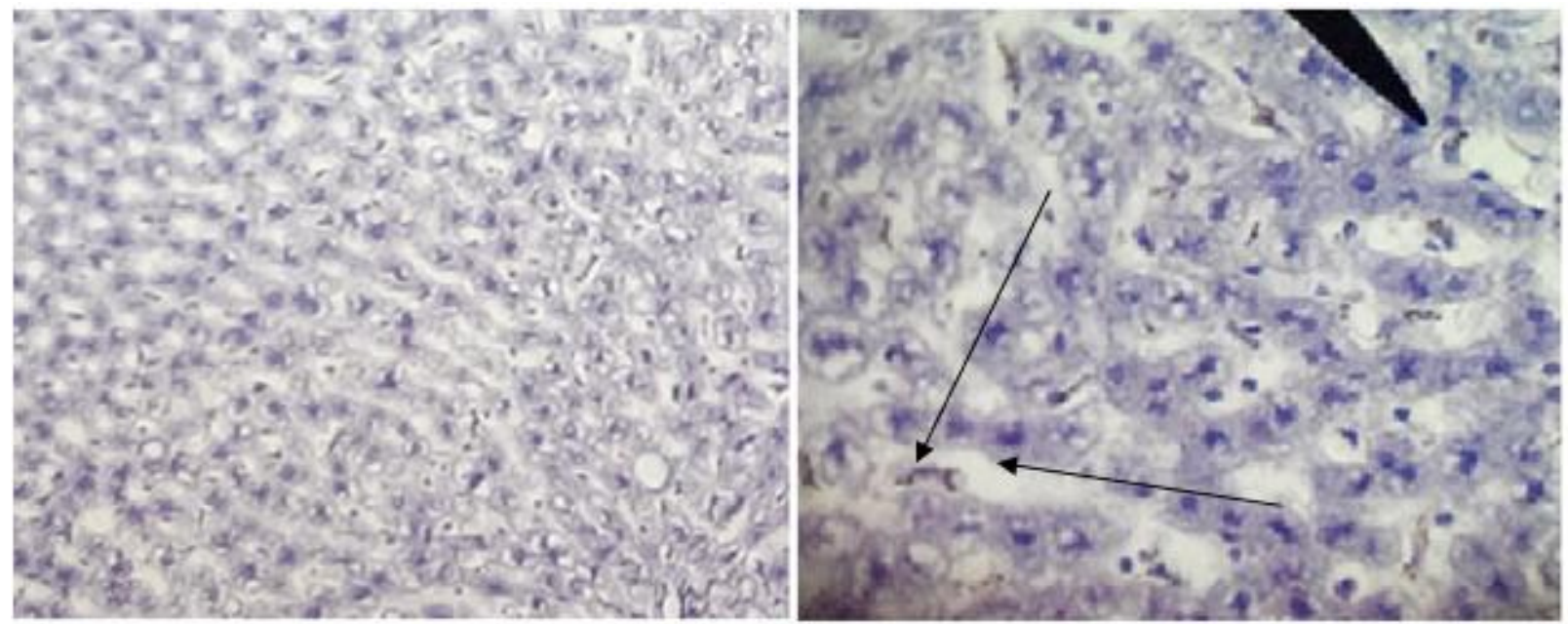

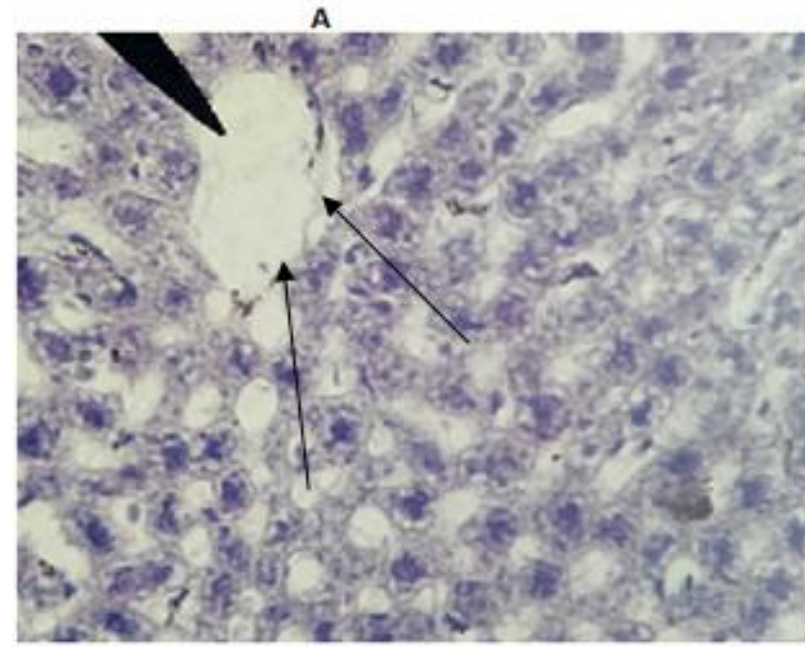

C

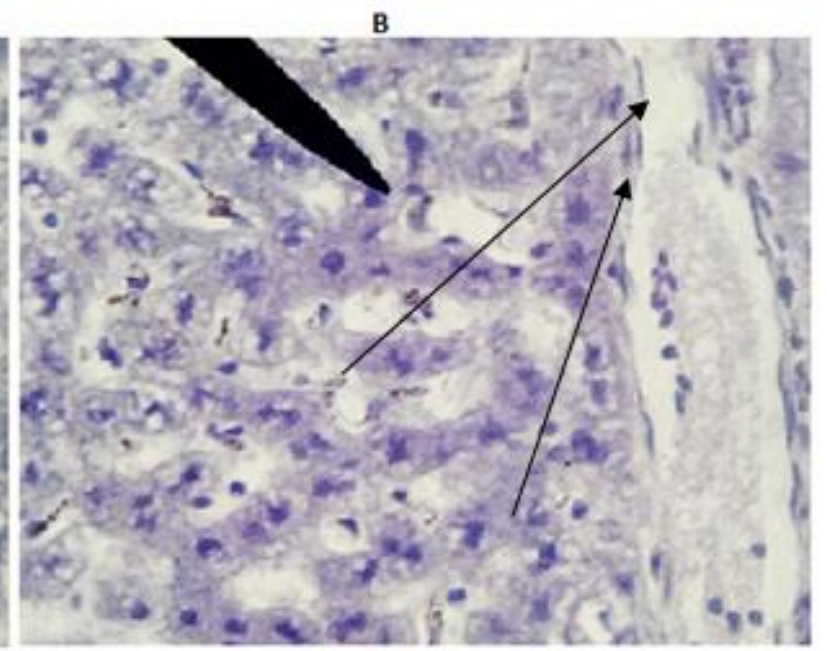

D

Figure 1. A) Control group exhibit very negligible lesion. B) Group treated 60mg.kg-1 body/Weight $(\mathrm{B} / \mathrm{W})$ dose exhibit that moderate bile duct hyperplasia along with degenerative changes in hepatocytes $\mathrm{C})$ Group treated $70 \mathrm{mg} \cdot \mathrm{kg}-1$ (B/W) dose exhibit condensed nuclei of hepatocytes and necrosed hepatocytes. D) Group treated $85 \mathrm{mg} \cdot \mathrm{kg}-1(\mathrm{~B} / \mathrm{W})$ dose exhibit that bile duct and hepatocytes necrosis of hepatocytes

\section{Discussion}

Blood is always an important and the key diagnostic tool to evaluate the toxic effect of xenobiotic which include pyrethroid pesticides and it can assess easily. Blood is off course very vital for survival. Therefore it is establish that assessment to evaluating serum biochemistry, if there is an amendment of any constituent of blood for which always considered suitable parameters should be there $[21,22]$.

In different perspective we have seen the high action of enzymes ALP, AST, ALT, and $\mathrm{LDH}$ as well as like of those other molecules in the serum of intoxicated rats with pyrethroid that can be manifested by pyrethroid toxicity induction. If we see in the general manner then the hepatocellular 
injury and mitochondrial damage activities are related to ALT and AST respectively. In most of the cases the amplified aminotransferase (AST and ALT) serum's activity shows impairment in the hepatocellular under pyrethroid strain which leads toward the leakage of these enzymes into general circulation [23-25]. Moreover it is fact that the xenobiotic metabolism took place in liver which is a key organ in this regard. Mostly it is seen that leakage of these enzymes in blood are predominately due to the processing of pyrethroid in liver and this particular effect can cause the hepatocellular damage under the effect by production of metabolically toxic intermediates which are available in the body [26].

In the present study we have also raveled that consequence of pesticide intoxication can be more pronounced by the pathophysiological changes in liver as a consequence by the elevated activity of serum alkaline phosphatase (ALP) and it is also possibly due to break in permeability of membrane of hepatocytes, as a result we have observed the seepage of this enzyme into the blood stream, as cypermethrin is proficient of changing normal structure of the hepatocellular in different fashion [27, 28, 25]. According to different studies in common observation the cholestasis caused by obstruction of its passage through the bile duct through the effect of regurgitation of enzymes. It is also been observed that back pressure outcome is discharge of the enzyme into blood and ultimately increasing its concentration. Moreover the enhanced levels of ALP in blood shows that it is an early indicator of cholestasis and elevated activity of hepatic AST, ALT and LDH along with a rise in serum bilirubin level [29]. If we look at the hepatic tissue demolition (necrosis), additionally might have accounted for raised level of ALP in the serum. Most of time there is observations shows that pesticide treatment can cause the degeneration of hepatic parenchymal cells so in this manner that resulting in raising of the levels by releasing of the enzymes into the circulating blood stream, [22, 25, 28, 30-33]. Furthermore in different studies it is also revealed that lysis of the red blood cell membrane pronounced due to pyrethroid haemolytic anemia, so as a result of this raised LDH (Lactate dehydrogenase) levels in serum of influenced rats of Pyrethroid treatment $[21,22,33,34]$.

It has also observed that hypoxic conditions in liver of intoxicated rats ultimately occur by type II pyrethroid pesticides which have the powerful ability to produce the genotoxic effect which furthermore participates to over expression of many enzymes (AST, ALT, ALP and LDH) at the gene level in particular cells [26, 35-37]. As we know it is established that bilirubin is produced from hemoglobin that is present in the reticulo-endothelial system, and after that it circulates and ultimately attached to plasma albumen. It is estimated that almost $80 \%$ of bilirubin which is circulating in the system is derived from red blood cells and the $20 \%$ remaining bone marrow cells being resultant from the ineffective erythropoiesis by the effect of destruction of erythroid cells [38].

As it is established that bilirubin metabolism takes place in liver which always plays a important role. In case of any damage to liver cells, which possibly was inflammation in the present study resulting in problem of bile excretion got disturbed, which can be responsible for hyperbiliribinemia in intoxicated rats due to pyrethroid [39-41].

Pyrethroid has a profound influence on proteins and ultimately it requires the cellular activity which is important in the process of fluid homeostasis. Xenobiotic substances can increase the Globulin concentration under stress [42-45]. 
According to studies the toxic effect of bifenthrin probably is due to its stresscausing effect [46]. In general observation the release of adrenocorticotropic hormone under stress condition producing the large amount of cortisol from the adrenal cortex [47], the end result of this cellular activity is storage of cellular protein stores, not including in liver. Additionally it is fact that production of the plasma protein from liver were moved into blood, so the protein level raised.

It is also revealed from many references that pyrethroid has effect on lipids that include triglycerides, free fatty acids, phospholipids and cholesterol [48]. It has been observed that total lipid concentration in serum was due to elevated level of above mentioned forms and that causes interruption of carbohydrate metabolism under the effect of raised total lipid level which appears to be and it is a cause of the possible cytotoxic effect of Pyrethroid on cells of the pancreas leading to relative deficiency of insulin [49] and glucose transport in cells cannot make possible due to the insulin deficiency in the body tissues because carbohydrate not available to these tissues. We can also say that in insulin deficiency, energy is derived from fats because to fulfill the energy demands of body carbohydrates are not sufficient. Storage of the fat in adipose tissue is then go under the process of hydrolization and thus the level of free fatty acids in blood was raised consequentially total lipid concentration was elevated in the serum [50-52].

Xenobiotic substances trigger the sympathetic nervous system; as a result adrenal medulla released the high amount of epinephrine and norepinephrine. It is also been observed that receptor sensitivity of hormone initiate the release of triglyceride lipase in tissues as a result the stored triglyceride undergo the process of hydrolysis an then fat which stored was mobilized to free fatty acid into the blood stream resulting of high serum total lipid concentration $[50,53]$.

In the present investigation under pyrethyroid stress elevated levels of cholesterol in serum observed and cholestasis occur as a resultant, as well as endogenous cholesterol synthesis.

From the present study the results overall suggest that pesticides containing pyrethroid is potentiate to create the strong toxic effect to alter normal body physiology. On the other hand, the effects can be normalized with passage of time, as observed in the improvement sets.

\section{Conclusion}

In conclusion, Pyrethroid especially bifenthrin, which is also a commonly used insect killer, has potentially disturb normal blood biochemistry of mammals. Taking into account the different biochemical parameters such as liver enzymes like AST, ALT, ALP, phospholipids, total lipids, glycerides, total proteins and most importantly It was observed that a higher concentration of bifenthrin raised the level of cholesterol and LDL in all the treated groups while the HDL level decreases in treated group was higher as compared to normal rats cholesterol. In albino rat's all physiochemical parameters were distressed considerably subsequent pyrethyroid toxic effect in dose and time dependent fashion. In addition it has observed that bile duct hyperplasia along with degenerative changes in hepatocytes by histopathological examination of liver and there was dose dependent severity. This underscores the use of proper precautionary measures should be taken in this regard to use of this pesticide (Bifenthrin) and to avoid any liver injury and dysfunctional blood biochemistry.

\section{Authors' contributions}

Conceived and designed the experiments: $\mathrm{T}$. Mehmood, Performed the experiments: MS Ikram, F Siddiue, IA Sattar \& Q Tabassam, 
Analyzed the data: T Mehmood \& Z Jabeen, Contributed: Reagents/ materials/ analysis tools: T Mehmood, Wrote the paper: $T$. Mehmood \& MS Ikram.

\section{Refrences}

1.Abdel-Rahim EA, Abdel-Rahim GA, Fayed SA \& Mahmoud GI (2009). Antioxidant diet as protective agents against biochemical perturbation effects induced by cypermethrin on lipids and protein fractions as well as kidneys function of blood rat. Aust J Appl Sci 3: 267-276.

2.Ahmad L, Khan A \& Khan MZ (2011). Cypermethrin induced biochemical and hepato-renal pathological changes in rabbits. Int J Agri Bio 13: 865-872.

3.Attia AM \& Nasr HM (2009). Evaluation of protective effect of omega-3 fatty acids and selenium on paraquat intoxicated rats. Solak J Animals 42: 180-187.

4.Bifenthrin Pesticide Fact Sheet (1988). U.S. Environmental Protection Agency Office of Prevention Pesticides, and Toxic Substances Washington, DC.

5. Azmi MA, Naqvi Azmi MA \& Aslam M (2006). Effect of pesticide on health and different enzymes levels in the blood of farm workers from Gadap (rural area) Karachi- Pakistan. J Chemo 10: 173944.

6. Awaad MHH, Abdel-Alim GA, Sayed KSS, Ahmed A, Nada AA, Metwalli ASZ \& Alkhalaf AN (2010). Immuno stimulant effects of essential oils of peppermint and eucalyptus in chickens. Pak Vet J 30: 61-66.

7. Bhushan B, Saxena PN \& Saxena N (2013). Biochemical and histological changes in rat liver caused by cypermethrin and beta-cyfluthrin. Toks J 64: 57-67.

8. Bhushan B, Saxena N \& Saxena PN (2010). Beta-cyfluthrin induced histochemical alteration in the liver of the albino rat. J Anim Sci 37: 61-66.

9. Carvalho WA (1991). Risk factors related with occupational and environmental exposure organochlorine insecticides in the state of Bahia, Brazil. J Bio 111: 512-24.

10. El-Demerdash FM, Yousaf MI \& Elagamy EI (2001). Influence of paraquat, glyphosphate and cadmium on the activity electrophoretic behavior (in vitro). J Envior Sci Health 36: 29-42.

11. El-Magd SAA, Sabik LME \& Shoukry A (2011). Pyrethroid toxic effects on some hormonal profile and biochemical markers among workers in pyrethroid Insecticide Company. Life Sci $J$ 8: 311-322.

12. El-Tawil OS \& Abdel-Rehman MS (2011). The role of enzyme induction and inhibition on cypermethrin hepatotoxicity. J Pharmacol 44: 33-40.

13. Fetoui H, Garoui EM \& Zeghal N (2009). Lambda-cyhalothrin-included biochemical and histo-pathological changes in the liver of rats. $J$ Toxicol 61: 189-196.

14. Guyton AC \& Hall JE (2001). Textbook of Medical Physiology. $10^{\text {th }}$ ed. Prism Books Limited, Bangalore, India.1148p.

15. Polish Physiological (2015). Soc J physio pharmcol 66(1): 129-37.

16. Gupta PK \& Kumar S (1991). Cumulative toxicity of deltamethrin in mice. $J$ Envior Biology 12: 45-50.

17. Harper HA, Rodwell VW \& Mayers PA (1979). Review of physiological chemistry. $2^{\text {nd }}$ ed.; Middle East 2: 130 146.

18. Hartley D \& Kidd H (2005). The Agrochemicals Handbook, 2nd edition. Royal Society of Chemistry, Cambridge, UK 6: 29-55.

19. Hernandez FA, Gomez MA, Perez VG, Lario VJ, Pena G \& Gill F (2006). Influence of exposure to pesticides on serum components and enzyme activities of cytotoxicity among intensive agricultural farmers. $J$ Environ 102: 70-76.

20. Zar JH. (1996): Biostatistical Analysis. 3rd ed. PrenticeHall, New Jersey. 718 pp. 
21. Hayes WJJR \& Laws ER (1991). Handbook of Pesticide Toxicology. Vol. 3.Academic Press Inc.; San Diego, New York 3: 1190.

22. Harisson TR 1994. Principles of Internal Medicine. 1994. McGraw Hill, New York, $154 \mathrm{p}$.

23. Javed MTL, Ahmad M, Irfan I, Ali A, Khan M, Wasiq FA, Farooqi MS, Latif \& Magiola (2010). Haematological and serum protein values in tuberculin reactor and non-reactor water buffaloes, cattle, sheep and goats. Pak Vet J 30: 100-104.

24. Kalender S, Ogutcu A, Uzunhisaracikli M, Acikzoz F, Durak D, Ulusoy Y \& Kalender Y (2005). Diazonin induced hepatotoxicity and protective effect of vitamins $\mathrm{E}$ on some biochemical indices and ultra-structural changes. $J$ Toxicol 21: 197-206.

25. Khan IA, Khan A, Hussain A, Riaz A \& Aziz A (2011). Hematobiochemical alterations in cross bred cattle affected with bovine theileriosis in semi-arid zone. Pak Vet J 31: 137-140.

26. Khan WA, Khan MZ, Khan A \& Hussain I (2010). Pathological effects of aflatoxin and their amelioration by vitamin E in White Leghorn layers. Pak Vet J 30: 155-162.

27. Kale M, Rathore N, John S \& Bhatnagar D (1999). Lipid peroxidative damage on pyrethroid exposure and alterations in antioxidant status in rat erythrocytes: a possible involvement of reactive oxygen species. J Toxicol 105: 197-205.

28. Khan A, Faridi HA, Ali M, Khan M, Siddique MZ, Hussain M \& Ahmad M (2009). Effects of cypermethrin on some clinico-hemato-biochemical and pathological parameters in male dwarf goats (Capra hircus). J Toxicol 61: 151-160.

29. Mancini F, Van Bruggen AHC, Jiggins JLS, Ambatipudi AC \& Murphy $\mathrm{H}$ (2005). Acute pesticide poisoning among female and male cotton growers in India. Int J Environ Health 11: 221232.

30. Michale JE, Ketehun NS \& Longneeker MP (2001). Serum dioxin and hepatic abnormalities in veteran of operation Ranch Hand. J Epidemol 5: 304-11.

31. Misra UK, Nag D, Dhushan V \& Ray, P.K. Clinical and biochemical changes in chronically exposed organophosphate workers. J Toxicol 244: 93-187.

32. Manni S, Bhattachryya D, Mandal TK \& Das S (2004). Repeated dose toxicity of alfacypermethrin in rats. $J$ Vet 3: 24145.

33. Nair RR, Abraham MJ, Lalithakunjamma CR, Nair ND \& Aravinda Kshan CM (2010). Hematological and biochemical profile in sub-lethal toxicity of cyper methrin in rats. Int $J$ Bio 1: 211-214.

34. Nair RR, Abraham MJ, Lalithakunjamma CR, NaiR ND \& Aravindakshan CM (2011). A pathomorphological study of the sublethal toxicity of cypermethrin in Sprague Dawley rats. Int $J$ Nutr Pharmacol 1: 179-183.

35. Nawaz SK, Batool R, Arshad M \& Arshad N (2010). Alpha tocopherol may reduce endosulfan induced toxicity in mice. Pak J Zoo 42: 205-210.

36. Pande S (2001). Effect of synthetic pyrethroids on certain haematobiochemical parameters of Rattusnorvegicus. Ph.D. Thesis, Dr. B.R. Ambedkar University, Agra.

37. Rana N, Saxena N, Sharma HN \& Saxena PN (2008). Comparative genotoxicity of alpha-cyanopyrethroids on Drosophila melanogaster. J Entamol 33: 135-138.

38. Rani S \& Dua KK (1999). Cypermethrin toxicity induced histological and biochemical changes in the liver of albino rats (Rattusnorvegicus). $J$ Ecoto Environ 9: 41-46.

39. Rezg R, Mornagui B, Kamoun A \& ElFazza Gharbi N (2004). Effect of subchronic exposure to matathion on metabolic parameters in rats. $C R J$ Bio 330: 143-147. 
40. Remor AP, Totti CC, Moreira DA, Dutra GP, Heuser VD \& Boeira JM (2009). Occupational exposure of farm workers to pesticides:Biochemical parameters and evaluation of genotoxicity. $J$ Environ Int 35: 273-278.

41. Saxena P \& Saxena AK (2010). Cypermethrin induced biochemical alterations in the blood of albino rats. Jordan J Bio Sci 3: 111-114.

42. Saxena PN \& Sharma DC (1999). Effect of hafen 20 EC on brain cholesterol, glycogen and total lipids in albino rat. Indian J Environ Toxicol 9: 72-73.

43. Soares W, Almeida RMVR \& Moro S (2003). Rural work and risk factors associated with pesticide use in Minas Gerais, Brazil J 19: 1117-1127.

44. Stonard MD, Evans GO, Ballantyne B, Marrs T \& Turner P (1995). General and Applied chemistry. Toxicol, Macmillan Press, London. 247.

45. Singh VK \& Saxena PN (2001). Effect of Cybil (cypermethrin 25EC) and Cybilsevin (carbaryl 50EC) combination on liver and serum phosphates in wistar albino rats. J Ecophysiol 1: 229-234.

46. Singh VK, Dixit P \& Saxena PN (2005). Cybil induced hepatobiochemical changes in wistar rats. $J$ Environ 26: 725-727.

47. Singh AK, Saxena PN \& Sharma HN (2009). Stress induced by betacyfluthrin, a type- 2 pyrethroid, on brain biochemistry of albino rat (Rattusnorvegicus). J Bio 1:74-86.
48. Singh VK \& Saxena PN (2002). Genotoxic potential of cypermethrin in mammalian haemopoietic system. J Environ Zoology 16: 195-202.

49. Tortora GJ \& Grabowski SR (2003). The digestive system. In: Principles of Anatomy and Physiology. John Wiley \& Sons. Inc USA. 851-903.

50. Vaittinen SL, Komulainen H, Kosma VM, Julkunen A, Mäki-Paakkanen J, Jansson K, Vartiainen T \& Tuomisto J (1995). Subchronic toxicity of 3-chloro-4 (dichloromethyl)-5-hydroxy-2 $(5 \mathrm{H})$ furanone (MX) in Wistar rats. J Food Chem Toxicol 33: 1027-1037.

51. Yousaf MI, Awad TI \& Mohammad EH (2006). Deltamethrin- induced oxidative damage and biochemical alterations in rat and its attenuation. Vet $J$ Toxicol 227: 240-47.

52. Yavasoglu A, Sayim F, Uyanikgil Y, Turgut M \& Yavasoglu NUK (2006). The pyrethroidcypermethrin induced biochemical and histological alterations in rat liver. J Health Sci 52: 774-780.

53. Brijender Bhushan B, Sunita Pande S, Nishi Saxena N \& Prabhu Narain Saxena PN (2013). Serum biochemical responses under stress of cypermethrin in albino rat. Environ Exp Bio 11: 8189. 